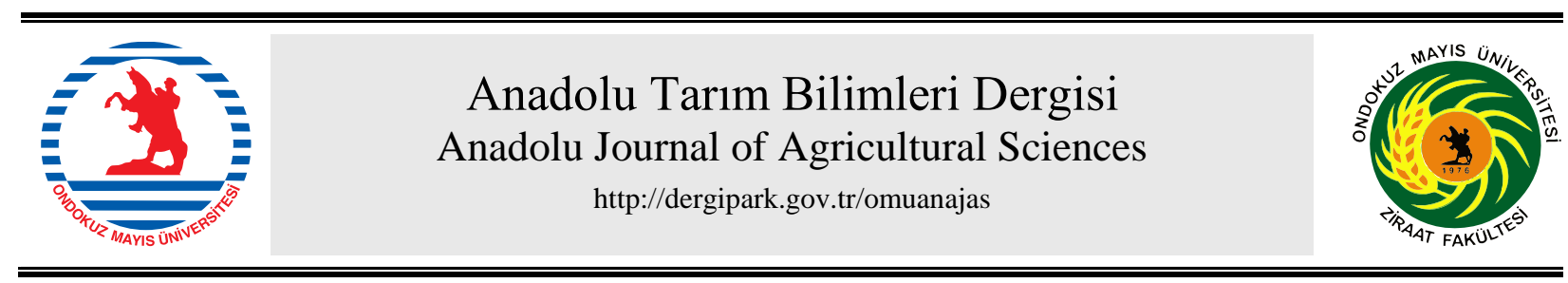

Araştırma/Research

Anadolu Tarım Bilim. Derg./Anadolu J Agr Sci, 36 (2021)

ISSN: 1308-8750 (Print) 1308-8769 (Online)

doi: 10.7161/omuanajas.868341

\title{
Iğdır ilindeki çiftçi örgütlerinin mevcut durumu ve yönetici profili
}

\author{
•Bakiye Kılıç Topuz ${ }^{\mathrm{a}^{*}}$ \\ ${ }^{a}$ Iğdır Üniversitesi, Ziraat Fakültesi, Tarım Ekonomisi Bölümü, Iğdır, Türkiye \\ *Sorumlu yazar/corresponding author: bakiyekilic@hotmail.com \\ Geliş/Received 26/01/2021 Kabul/Accepted 28/04/2021
}

\begin{abstract}
ÖZET
Iğdır ilinde hane halklarının önemli bir kısmının temel geçim kaynağını tarımsal faaliyetler oluşturmaktadır. Çiftçi örgütleri, tarım sektöründe faaliyet gösteren işletmelerin mesleki ve ekonomik ihtiyaçlarının karşılanmasında önemli bir araçtırlar. Araştırmanın amacı, Iğdır ilindeki tarımsal örgütlerin mevcut durumu ve yönetici profillerinin ortaya konulmasıdır. Araştırmanın ana materyalini, Iğdır ilindeki çiftçi örgütlerinin yöneticileriyle yapılan anketlerden elde edilen veriler oluşturmaktadır. Araştırma sonuçlarına göre, aktif üye oranı (\%13.3) oldukça düşük olan tarımsal örgütlerin etkili olarak faaliyet göstermediği, üyelerine verdikleri hizmetlerin çok yetersiz, en önemli sorunlarının finansman ve üyelerin genel kurula katılım oranının çok düşük olduğu belirlenmiştir. Tarımsal örgüt yöneticilerinin ise \%50'sinin üniversite mezunu, yılda ortalama $1.25 \mathrm{kez}$ kongre, seminer, fuar gibi etkinliklere katıldıkları, bölgedeki tarım paydaşları ile ilişkilerinin zayıf ve örgütlenme eğitimi alma durumlarının ise çok düşük olduğu belirlenmiştir. Iğdır ilindeki çiftçi örgütlerinin etkili olarak faaliyet gösterebilmesi için üreticilere ve yöneticilere örgütlenme konusunda eğitim verilmesi, örgütlerin sermayelerinin, üyelerin genel kurula katılım oranının, aktif üye sayısının, üyelerine verdikleri hizmetlerin ve proje hazırlama ve yürütme kapasitelerinin artırılması gerekli görülmektedir.
\end{abstract}

Current situation and the profiles of executive board of the agricultural farmers organizations in Igdir province

\section{ABSTRACT}

Agricultural activities constitute the main source of income for a significant portion of the households in Igdir. Farmers' organizations are an important tool in meeting the professional and economic needs of businesses operating in the agricultural sector. The aim of this research was to expose the current situation and the profiles of executive board of the agricultural organizations in Igdir province. The data of this research was collected through surveys from the executive board of farmer organizations. The results of the research revealed that the rate of active members in the agricultural organizations was very low (13.3\%) and these organizations were not effectively operated and they also could not provide sufficient services to their members. The most important problem of these organizations was determined as financing obstacles and low participation rate of members into the general assembling. Half of the executive board members graduated from university and they attended averagely 1.25 times into the events related with their organizations such as congress, seminar and fairs. Their relationships with the agricultural stakeholders and the level of organizational training were weak. In order to manage farmer organizations in Igdir province effectively, it is necessary to provide training to their executive board and members, to increase their capital, the participation rate of the members to the general assembly, the number of active members, their services to the members and their project preparation and execution capacities.
Anahtar Sözcükler: Tarımsal çiftçi örgütleri Mevcut durum analizi Yönetici profili Iğdır

Keywords:

Farmers organizations

Current situation

Executive board profile Igdir

(c) OMU ANAJAS 2021 


\section{Giriş}

Örgütlenme, benzer sorunlara sahip kişi ve kurumların birlikte hareket ederek sorunlarını dile getirmek ve çözmek, üretimde bulunmak ve bunlarla ilişkili hizmetleri yerine getirmek amacıyla bir araya gelmeleri olarak tanımlanmaktadır (Rehber, 1993; Talim ve ark., 1981). Örgütler, dünyanın birçok ülkesinde bireyler ve dolayısıyla toplumun daha iyi bir hayat sürdürmelerine katkı sağlamaktadırlar. Gelişmiş ve gelişmekte olan ülkelerde sosyal ve ekonomik kalkınmanın temeli kooperatiflere dayanmakta olup, dünyada demokrasinin yaygınlaşması, barışın sağlanması, çevrenin korunması, istihdam yaratma, kaynakları harekete geçirme ve yatırım oluşturmada önemli bir araç olarak kullanılmaktadır (Özüdoğru, 2004). Dünyada 3 milyondan fazla kooperatife 1 milyardan fazla kişi üye durumundadır. Kooperatifler dünyada 280 milyon kişiye sağladığı istihdam ile (dünya çalışan nüfusun \%10'u), sürdürülebilir ekonomik büyümeye ve istihdama katkıda bulunmaktadır. Dünyanın 2017 yılı verilerine göre en büyük üç yüz kooperatifinin 2,034,98 milyar \$ cirosunun \%31.7'si tarım sektöründe faaliyet gösteren kooperatifler tarafindan gerçekleştirilmiştir (ICA, 2021).

Türkiye'de tarım sektöründeki üreticiler, ekonomik ve sosyal amaçlı örgütler ile mesleki amaçlı örgütlerin çatıs1 altında bir araya gelmektedirler. Ekonomik ve sosyal amaçlarla tarım kooperatifleri, tarımsal üretici birlikleri, yetiştirici birlikleri, sulama birlikleri ve tarımsal vakıflar şeklinde örgütlenme modelleri kurulurken, mesleki amaçlarla ziraat odaları ve çiftçi dernekleri çatısı altında bir araya gelinmektedir (Çizelge 1). Türkiye'de çeşitli tarım konularında faaliyet göstermek üzere kurulan 14,457 adet tarımsal örgüt olup, bu örgütlere 10,123,745 çiftçi üyedir (TRGM, 2021).

Türkiye'nin en doğusunda ve Doğu Anadolu Bölgesi'nin Erzurum-Kars bölümünde yer alan Iğdır ili, Kars ilinden 27 Mayıs 1992 tarihinde ayrılarak Türkiye'nin 76. ili olmuştur. Iğdır ili Merkez ilçe ile birlikte 4 ilçe ve 157 köyden oluşmaktadır. İlin kuzeydoğu sınırını Aras nehri ve nehrin yatağı boyunca Ermenistan sınıı, doğu ve güneydoğu sınırını Nahcivan ve İran, güney sınırını Ağrı ili, batı ve kuzeybatısını ise Kars ili oluşturmaktadır. Azerbaycan (Nahcıvan), İran ve Ermenistan'a sınır komşusu olan Iğdır ilindeki hane halklarının önemli kısmının temel geçim kaynağını tarımsal faaliyetler oluşturmaktadır (Anonim, 2020). Iğdır ili, Türkiye'nin üç ülke ile sınır kapısı olan tek ili konumunda olması ülke ekonomisi için büyük önem taşımaktadır. Iğdır ilinin nüfusu ise 2019 yılına göre 196,725'dir (TÜIK, 2020).

Araştırma kapsamında yapılan literatür araştırması sonucunda, tarımsal örgütlerin mevcut durumu ve sorunlarını inceleyen çok sayıda araştırmaya rastlanılmışıır. Şöyle ki; Everest ve ark. (2019) Çanakkale ilindeki Kılıç Topuz ve Bozoğlu (2016), Kılıç Topuz ve Bozoğlu (2018) Samsun ilindeki Ünal ve ark. (2011) Ege Bölgesindeki Yücel ve Acar (2018) Sinop ilindeki Aydoğdu ve ark. (2014) Harran Ovası'ndaki Çiftçi (2015) Konya ilindeki Yılmaz ve Gül (2010) Adana ilindeki Bozoğlu ve ark. (2001) Tonya ilçesindeki tarımsal örgütlerin mevcut durumlarını, Serinikli ve Kumkale (2012) ise Türkiye'deki bölge birliklerinin mevcut durumlarını incelemişlerdir. Tarımsal örgüt yöneticilerinin profili ve özellikleri konusunda yapılan araştırmalar ise daha sınırlıdır. Tarımsal örgüt yöneticileri konusunda yapılan çalışmalar; Türkiye'deki tarımsal kalkınma kooperatifleri yöneticileri (Şahin ve ark., 2015), Harran Ovası sulama birlik başkanları (Aydoğdu ve ark., 2015), Sinop ili su ürünleri kooperatif yöneticileri (Yücel ve Acar, 2018) ve Çanakkale ili tarımsal örgüt yöneticileri özellikleri (Everest ve ark., 2019) şeklindedir. Iğdır ilinde ise tarımsal örgütlenme konularında çok sınırlı sayıda araştırma yapılmış ve yapılan araştırmalarda kırsal kalkınma kooperatifi üyelerinin örgütlenme ve kooperatif faaliyetleriyle ilgili problemleri (Karadaş ve ark., 2015), tarım işletmelerinde örgütlenme bilinci (Karadaş ve ark., 2014), hayvancıllı işletmelerinin üretim ve pazarlamada yaşadıkları örgütlenme sorunlarının analizi (Alptekin, 2018) üzerinedir. Buna karşın, Iğdır ilinde tarımsal örgütlerin (birlik ve kooperatif) mevcut durumunu ve yönetici profilini ortaya koyan bir araştırmaya rastlanılmamıştır. Yapılan araştırmanın literatürdeki bu yöndeki boşluğu doldurması beklenmektedir. Araştırmanın amacı, Iğdır ilinde faaliyet gösteren tarımsal örgütlerin mevcut durumunun ve yönetici profillerinin ortaya konulmasıdır. 
Çizelge 1. Türkiye'de ve Iğdır ilinde tarımsal örgüler ve üye sayıları

Table 1. Number of agricultural organizations and members in Igdir province and Turkey

\begin{tabular}{|c|c|c|c|c|c|c|c|}
\hline \multirow{2}{*}{\multicolumn{2}{|c|}{ Çiftçi Örgütleri }} & \multicolumn{3}{|c|}{ Türkiye } & \multicolumn{3}{|c|}{ Iğdır İli } \\
\hline & & Say1 & $\%$ & Üye Sayıs1 & Say1 & $\%$ & Üye Sayısı \\
\hline \multirow{6}{*}{ 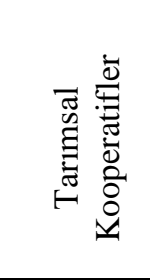 } & $\begin{array}{l}\text { Tarımsal Kalkınma } \\
\text { Kooperatifi (TKK) }\end{array}$ & 6,785 & 47.0 & 737,057 & 2 & 18.1 & 103 \\
\hline & Sulama Kooperatifi & 2,474 & 17.1 & 319,167 & - & - & - \\
\hline & Su Ürünleri Kooperatifi & 567 & 3.9 & 30,611 & - & - & - \\
\hline & Pancar Ekicileri Kooperatifi & 31 & 0.2 & $1,397,191$ & - & - & - \\
\hline & Tarım Kredi Kooperatifi & 1,625 & 11.2 & 809,725 & 4 & 36.3 & 1,933 \\
\hline & Tarım Satış Kooperatifi & 338 & 2.3 & 332,925 & - & - & - \\
\hline \multicolumn{2}{|c|}{ Kooperatif Toplam } & 11,820 & 81.7 & $3,626,676$ & 6 & 54.4 & 2,036 \\
\hline \multirow{3}{*}{ 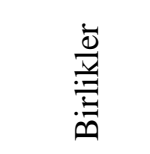 } & Tarımsal Üretici Birlikleri & 867 & 6.0 & 345,686 & 1 & 9.1 & 144 \\
\hline & Yetiştirici Birlikleri & 277 & 1.9 & 571,705 & 3 & 27.2 & 3,340 \\
\hline & Sulama Birlikleri & 189 & 1.3 & 428,669 & - & - & - \\
\hline \multicolumn{2}{|c|}{ Birlik Toplam } & 1,333 & 9.2 & $1,346,060$ & 4 & 36.3 & 3,484 \\
\hline \multirow{3}{*}{ 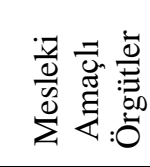 } & Ziraat Odaları & 765 & 5.2 & $4,921,009$ & 1 & 9.1 & 6,012 \\
\hline & Çiftçi Dernekleri & 525 & 3.6 & 227,500 & - & - & - \\
\hline & Tarımsal Vakıflar & 14 & 0.09 & 2,500 & - & - & - \\
\hline \multicolumn{2}{|c|}{ Mesleki Örgüt Toplam } & 1,304 & 8.8 & $5,151,009$ & 1 & 9.1 & 6,012 \\
\hline \multicolumn{2}{|c|}{ Genel Toplam } & 14,457 & 100.0 & $10,123,745$ & 11 & 100.0 & 11,532 \\
\hline
\end{tabular}

Kaynak: TRGM, 2021; Iğdır İl Tarım ve Orman Müdürlüğü, 2021.

\section{Materyal ve Yöntem}

Iğdır ilinde 2 tarımsal kalkınma kooperatifi, 4 tarım kredi kooperatifi, 1 tarımsal üretici birliği, 3 yetiştirici birliği ve 1 ziraat odası olmak üzere toplam 11 adet tarımsal örgüt ve bu örgütlere üye 11,532 çiftçi bulunmaktadır (Çizelge 1). Araştırmanın ana materyali, Iğdır ilinde bulunan Arı Yetiştiriciler Birliği (AYB), Damızlık Koyun Keçi Yetiştirici Birliği (DKKYB), Gaziler Tarımsal Kalkınma Kooperatifi ve Bulakbaşı Tarımsal Kalkınma Kooperatifi yöneticilerinden elde edilen veriler oluşturmaktadır (Şekil 1). Araştırmanın birincil verileri, kooperatif/birlik yöneticileriyle Eylül 2019 tarihinde yüz yüze yapılan anketlerden elde edilmiştir. Araştırmanın ikincil verileri ise Tarım ve Orman Bakanlığı, Türkiye İstatistik Kurumu (TÜİK), Tarım Reformu Genel Müdürlüğü, Iğdır Tarım ve Orman İl Müdürlüğü ve konu ile ilgili yapılan literatürden oluşmaktadır.

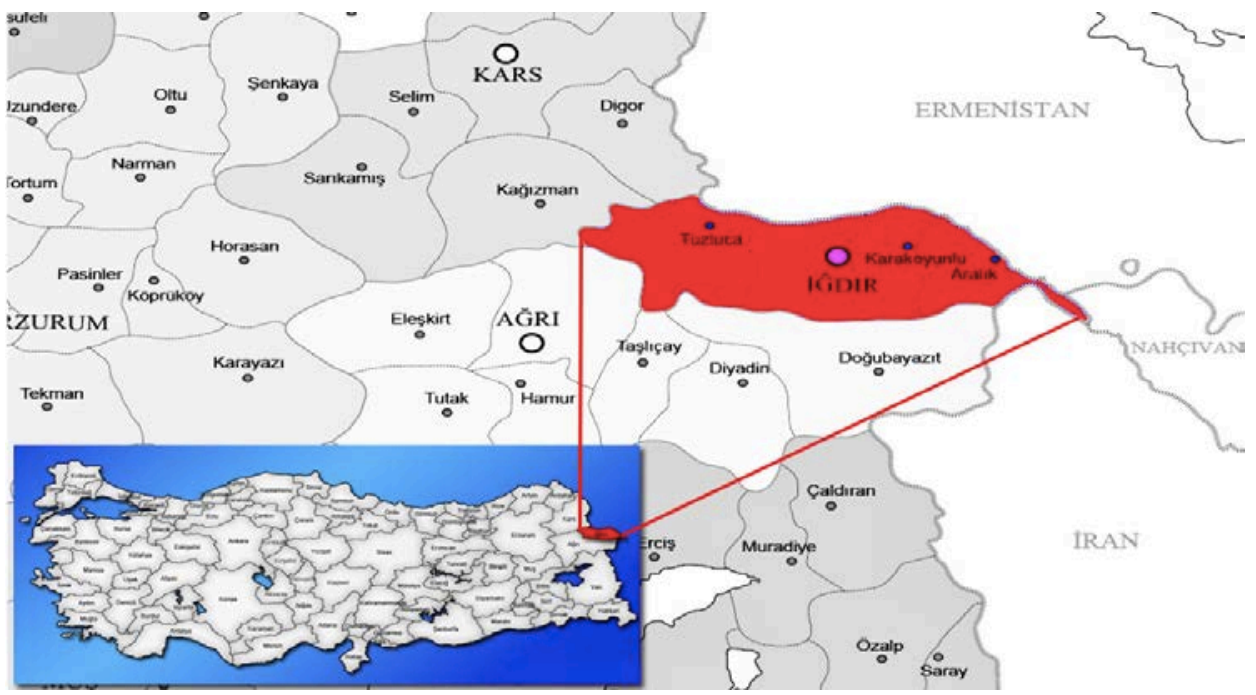

Şekil 1. Araştırma alanı

Figure 1. Research area 
Araştırmada Iğdır ilinde bulunan tarımsal örgütlerin yapısı, personel durumu, üyelere sağlanan hizmetler, sermaye varlığı, proje uygulama durumları, sorunlar ve sosyal ilişkileri ile birlikte yöneticilerin profili incelenmiştir. Araştırmanın bulguları, tanımlayıcı istatistikler şeklinde verilmiştir. Araştırma kapsamında tarım kooperatifleri ve birliklerin sorunları ve bölgedeki diğer tarım paydaşları ile ilişkilerinin belirlenmesinde 5'li Likert ölçeğinden (1: Önemsiz, ..., 5: Çok önemli) yararlanılmıştır.

\section{Bulgular ve Tartışma}

\subsection{Tarımsal örgütlere ait genel bilgiler}

Araştırma kapsamında ele alınan tarımsal örgütlerin yarısının faaliyet konusu büyükbaş hayvancılık iken, \%25'inin arıcılık ve \%25'inin de koyun ve keçi yetiştiriciliğidir. Tarımsal örgütlerden Arı YB 2005 yılında, Koyun Keçi YB 2006 yılında ve TKK'leri ise 2007 yılında kurulmuşlardır. Tarımsal örgütlerden Koyun Keçi YB 2,414 ile en fazla üyeye sahipken, köy bazlı hizmet veren kooperatifler ortalama 52 üyeye sahiptir. Yetiştirici Birlikleri 4 ilçe ve 50 köye hizmet vermekte olup, ortalama bir kişi istihdam edilmektedir. Everest ve ark (2019) tarafindan Çanakkale ilinde yapılan araştırmada ise tarımsal örgütlerin ortalama 2.16 köye hizmet verdiği ve çalışanların 0.46 kişi olduğu tespit edilmiştir. Ünal ve ark. (2011) tarafından Ege Bölgesindeki su ürünleri kooperatiflerinde yapılan araştırmada kooperatiflerin tamamına yakınında ücretli olarak herhangi birinin çalıştırılmadığı belirlenmiştir. Araştırma kapsamında ele alınan tarımsal örgütlerde son yıl yapılan genel kurul toplantılarına üye katılım oranı \%26 gibi oldukça düşüktür. Üyelerin genel kurul toplantısına katılım oranı Gaziler TKK \%68 ile en fazla iken, Koyun Keçi YB \%5 ile en düşüktür. Kılıç Topuz ve Bozoğlu (2016) tarafından Samsun ilinde yapılan araştırmada ortalama 3 kişi istihdam edildiği ve üyelerin genel kurul toplantılarına katılım oranının düşük (\%23) olduğu belirlenmiştir. Araştırmada tarımsal örgütlerin \%50'si üyelerine, kayıt tutma, tarımsal üretimle ilgili eğitim, üretici örgütlenmesi konusunda eğitim, hayvan temini ve üretimle ilgili araç-gereç temini gibi hizmetler sağlamaktadır. Sadece Arı YB ürünlerin pazarlanmasına aracılık etmekte, sosyo-kültürel faaliyetler düzenlenmekte, gazete, dergi gibi basılı materyaller temini sağlamaktadır (Çizelge 2). Kılıç Topuz ve Bozoğlu (2015) tarafından Samsun ilinde yapılan araştırmada tarımsal kalkınma kooperatiflerinin \%77'sinin üyelere girdi temini yaptığı, \%66'sının hayvan temini sağladığı ve \%55'inin ise ortakların ürünlerini pazarladığı belirlenmiştir. Bozoğlu ve ark. (2001) tarafindan Tonya ilçesi tarımsal kalkınma kooperatifinin üyelerine süt işleme, pazarlama, ucuza girdi temini, süt alımı ve fiyat garantisi, piyasada rekabet ortamı yaratma gibi hizmetleri sağladığı belirlenmiştir. Buradan araştırma kapsamında ele alınan tarımsal örgütlerin üyelerine sağladıkları hizmetlerin çok yetersiz olduğu söylenebilir.

Çizelge 2. Tarımsal örgütlere ait genel bilgiler ve üyelere sağlanan hizmetler Table 2. General information about agricultural organizations and provided services to members

\begin{tabular}{|c|c|c|c|c|c|}
\hline & $\begin{array}{l}\text { Ar1 } \\
\text { YB }\end{array}$ & DKKYB & $\begin{array}{l}\text { Gaziler } \\
\text { TKK }\end{array}$ & $\begin{array}{l}\text { Bulakbaşı } \\
\text { TKK }\end{array}$ & $\begin{array}{l}\text { Ortalama/ } \\
\%\end{array}$ \\
\hline Birliğin faaliyet konuları & Ar1 & $\begin{array}{r}\text { Koyun } \\
\text { keçi }\end{array}$ & $\begin{array}{r}\text { Büyükbaş } \\
\text { hayvancıllk }\end{array}$ & $\begin{array}{r}\text { Büyükbaş } \\
\text { hayvancıllk }\end{array}$ & - \\
\hline Kuruluş yıl & 2005 & 2006 & 2007 & 2007 & - \\
\hline Mevcut üye sayısı (kişi) & 302 & 2,414 & 51 & 54 & 705 \\
\hline Aktif üye sayısı (kişi) & 170 & 117 & 51 & 40 & 94 \\
\hline Aktif üye oran (\%) & 56.2 & 4.84 & 100.0 & 74.0 & 13.3 \\
\hline Hizmet verilen ilçe sayısı & 4 & 4 & 1 & 1 & 2.5 \\
\hline Hizmet verilen köy sayıs1 & 50 & 50 & 1 & 2 & 25.75 \\
\hline Birlik/kooperatifte çalışan sayısı & - & 4 & - & - & 1 \\
\hline 2019 yılı genel kurula katılım oranı (\%) & 10.5 & 5.30 & 68.0 & 20.0 & 26.0 \\
\hline \multicolumn{6}{|l|}{ Üyelere/ortaklara sağlanan hizmetler } \\
\hline Çiftçi kaydı tutma & + & + & & & 50.0 \\
\hline Tarımsal üretimle ilgili eğitim & + & & + & & 50.0 \\
\hline Üretici örgütlenmesi konusunda eğitim & + & & + & & 50.0 \\
\hline Hayvan temini & & + & + & & 50.0 \\
\hline Üretimle ilgili araç-gereçler & & + & + & & 50.0 \\
\hline Ürünlerin pazarlanmasına aracılık etme & + & & & & 25.0 \\
\hline Sosyo-kültürel etkinlikler düzenleme & + & & & & 25.0 \\
\hline Gazete, dergi, vb basılı materyaller temini & + & & & & 25.0 \\
\hline
\end{tabular}




\subsection{Tarımsal örgütlerin sermaye durumu}

Araştırmada ele alınan tarımsal örgütlerin \%75'inde ortalama 175 TL giriş sermayesi alındığı, \%25'inde ise alınmadığı belirlenmiştir. Tarımsal örgütlerin tamamında üyelik aidatı alınmakta iken, birlik veya kooperatif üyelerinin üyelik aidatını her zaman ödeyenlerin oranı \%51.25'dir. Üyelerin \%5'i üyelik aidatını hiçbir zaman ödemezken, geriye kalan \%43.75’i üyelik aidatını ara sıra ve genellikle ödemektedirler. Örgütlerde üyelik aidatı en az 100, en fazla 200 TL'dir (Çizelge 3). Sermayesinden yedek akçe ayıran örgüt ise sadece Arı YB'dir.

Çizelge 3. Örgütlerde giriş sermayesi alınma ve üyelik aidatı ödenme durumları

Table 3. Invest capital and payment membership fees in organizations

\begin{tabular}{|c|c|c|c|c|c|c|c|c|}
\hline \multirow[b]{2}{*}{ Örgüt adı } & \multicolumn{2}{|c|}{ Giriş sermayesi } & \multicolumn{2}{|c|}{ Üyelik aidatı } & \multicolumn{4}{|c|}{ Üyelik aidatı ödeme sıklıkları (\%) } \\
\hline & $\begin{array}{l}\text { Alinma } \\
\text { durumu }\end{array}$ & $\begin{array}{r}\text { Miktar } \\
(\mathrm{TL}) \\
\end{array}$ & $\begin{array}{l}\text { Alınma } \\
\text { durumu }\end{array}$ & $\begin{array}{l}\text { Miktar } \\
(\mathrm{TL})\end{array}$ & $\begin{array}{l}\text { Hiçbir } \\
\text { zaman }\end{array}$ & $\begin{array}{l}\text { Ara } \\
\text { sira } \\
\end{array}$ & Genellikle & $\begin{array}{r}\text { Her } \\
\text { zaman } \\
\end{array}$ \\
\hline Ar1 YB & + & 250 & + & 100 & 20 & 50 & 20 & 10 \\
\hline DKKYB & + & 200 & + & 200 & - & 5 & - & 95 \\
\hline Gaziler TKK & - & 0 & + & 100 & - & - & - & 100 \\
\hline Bulakbaşı TKK & + & 250 & + & 65 & - & 100 & - & - \\
\hline $\begin{array}{l}\text { Ortalama/ } \\
\text { Oran (\%) }\end{array}$ & 75.0 & 175 & 100.0 & 116 & 5.0 & 38.75 & 5.0 & 51.25 \\
\hline
\end{tabular}

Tarımsal örgütlerin son üç y1l gelir-gider durumları Çizelge 4'den incelendiğinde, 2016 yılında ortalama 92,500 TL geliri, 80,250 TL gideri ve 12,250 TL kâr elde ettiği belirlenmiștir. Birlik/kooperatiflerin 2017 yılında ise kârının bir önceki yıla göre \%100 artarak 25,500 TL'ye çıktığı, 2018 yılında ise 14,750 TL'ye düştüğü görülmektedir. Araştırma kapsamında ele alınan tarımsal örgütlerden en fazla gelire DKKYB'nin, en düşük gelire ise tarımsal kalkınma kooperatiflerinin sahip olduğu tespit edilmiştir. DKKYB dışındaki diğer birlik/kooperatiflerin faaliyetlerini devam ettirebilmeleri için elde ettikleri gelirler çok yetersizdir. DKKYB'nin de gelirlerinin diğer örgütlerden fazla olmasının sebebi, hayvancıllk desteklemelerinin birlik aracıllğıyla verilmesinden kaynaklanmaktadır. Tarımsal destek başvuruları birlik aracılı̆̆ıyla alındığından, birlikler destekleme alan üyelerden yıllık üyelik aidatlarını, giriş sermayesini ve hayvan başına kesilen hizmet bedelini alabilmektedirler. Diğger tarımsal örgütlerde böyle bir durum söz konusu olmadığından gelirleri oldukça yetersiz kalmaktadır. Aydoğdu ve ark. (2015) tarafindan Harran Ovasındaki Sulama Birliklerinin de, Yücel ve Acar (2018) tarafından Sinop ili Su Ürünleri Kooperatiflerinin de gelirlerinin oldukça yetersiz olduğu belirlenmiştir.

Çizelge 4. Birliklerin/kooperatiflerin gelir-gider durumları (Bin TL/Yıl)

Table 4. Income-expense status of unions/cooperatives (Thousand TL/Year)

\begin{tabular}{|c|c|c|c|c|c|c|c|c|c|}
\hline \multirow{2}{*}{ Örgüt adı } & \multicolumn{3}{|c|}{2016} & \multicolumn{3}{|c|}{2017} & \multicolumn{3}{|c|}{2018} \\
\hline & Gelir & Gider & $\begin{array}{l}\text { Kâr / } \\
\text { zarar }\end{array}$ & Gelir & Gider & $\begin{array}{l}\text { Kâr / } \\
\text { zarar }\end{array}$ & Gelir & Gider & $\begin{array}{l}\text { Kâr / } \\
\text { zarar }\end{array}$ \\
\hline Ar1 YB & 15 & 14 & 1 & 17 & 15 & 2 & 42 & 20 & 22 \\
\hline DKKYB & 350 & 300 & 50 & 600 & 500 & 100 & 450 & 420 & 30 \\
\hline Gaziler TKK & 5 & 5 & 0 & 5 & 5 & 0 & 5 & 5 & 0 \\
\hline Bulakbaşı TKK & - & 2 & -2 & 2 & 2 & 0 & 20 & 13 & 7 \\
\hline Ortalama & 92,5 & 80,2 & 12,3 & 15,6 & 13 & 25,5 & 129,5 & 114,5 & 14,7 \\
\hline
\end{tabular}

Iğdır ili tarımsal örgütlerin yatırım sermayesi varlıkları Çizelge 5'den incelendiğinde; tarımsal örgütlerin \%25'inin kira, \%75'inin ise mülk kooperatif/birlik binası olduğu belirlenmiştir. Tarımsal örgütlerden sadece Arı YB'nin kullandığı binanın kira olduğu ve yıllık 3,600 TL kira ödediği, diğer tarımsal örgütlerin ise binalarının mülk olduğu belirlenmiştir. Everest ve ark. (2019) tarafından Çanakkale ilinde yapılan araştırmada ise tarımsal kalkınma kooperatiflerinin hizmet binasının \%42.67'sinin mülk, \%52'sinin kira olduğu, \%5.33'ünün ise kooperatif hizmet binası olmadığı tespit edilmiştir. Tarımsal örgütlerin kullandığı binalardan en geniş alana $240 \mathrm{~m}^{2}$ ile Koyun Keçi YB sahip iken, en küçük alana $40 \mathrm{~m}^{2}$ ile Arı YB sahiptir. Arı YB ve Koyun Keçi YB binalarını aktif olarak kullanmasına rağmen Gaziler TKK ve Bulakbaşı TKK'nın binalarını aktif olarak kullanmadıkları tespit edilmiştir. 
Tarımsal örgütler arasında sadece Gaziler TKK'nın süt soğutma tankı, silaj biçme makinası ve kırma makinası gibi alet makinaya sahip olduğu fakat, bu alet makinaları aktif olarak kullanmadığı belirlenmiştir.

Çizelge 5. Birliklerin/kooperatiflerin yatırım sermayesi varlıkları

Table 5. Investment capital assets of unions/cooperatives

Ar1 YB $\quad$ DKKYB $\quad$ Gaziler TKK $\quad$ Bulakbaşı TKK

\begin{tabular}{llrrrr}
\hline Bina & Kira (TL) & 3,600 & & & + \\
& Mülk & & + & + & 1 \\
& Kat sayı & 1 & 2 & 1 & - \\
& Büyüklük (m $\left.{ }^{2}\right)$ & 40 & 240 & 160 & - \\
& Aktif kullanım & + & + & - & \\
\hline Alet- & Süt soğutma tank1 & & & 5 ton \\
makina & Değeri (Bin TL) & & 50 \\
& Silaj biçme makinas & & 1 \\
& Değeri (Bin TL) & & 10 \\
& Kırma makinası & & 1 \\
& Değeri (Bin TL) & & 6 \\
\hline
\end{tabular}

Tarımsal örgütlerin daha etkili hale gelebilmesi, kırsal alanda üyelere gerekli hizmetlerin verilmesi, örgütlerin sermayelerinin güçlendirilebilmesi, üye-örgüt ilişkileri, üyelerin tarımsal gelirleri ve üye memnuniyetinin artırılabilmesi için projeye dayalı faaliyetlerinin geliştirilmesi gerekli görülmektedir (Kılıç Topuz ve Bozoğlu, 2015). Araştırma kapsamında ele alınan birlik ve kooperatiflerin \%75'inin en az bir proje uyguladığı, tarımsal örgütlerden sadece Bulakbaşı TKK herhangi bir proje uygulamadığı belirlenmiştir. Arı YB, Iğdır İl Özel İdaresi ve Tarım ve Orman Bakanlığı destekli iki ayrı proje yürütmüştür. İl Özel İdare destekli "Arı ile Gelen Refah Projesi”" nde canlı arı ve ilaç temini, Bakanlık destekli "Genç Çiftçi Projesi" nde ise 11 üye arıcıya 30 Bin TL, toplamda 330 Bin TL'lik destek ödemesi yapılmıştır. Damızlık Koyun Keçi YB ise Tarım ve Orman Bakanlı̆̆ı ve Serhat Kalkınma Ajansı (SERKA) destekli iki ayrı proje yürütmüştür. Bakanlık destekli "300 Koyun Projesi”nde 22 üyeye $\% 0$ faizle, 7 yıl ödemeli koyun dağıtımı yapılmıştır. Birliğin SERKA destekli projesinden ise üyelere 90 Bin TL değerinde Saanen keçisi dağıtılmıştır fakat, keçiler çevreye uyum sağlayamadığ 1 için istenen etki gerçekleştirilememiştir. Gaziler TKK'de 2009 yılında Tarım ve Orman Bakanlığı tarafından başlatılan "Damızlık Sığır Projesi" ile 50 kooperatif ortağına iki yıl sonra ödemeli 6'şar damızlık sığır dağıtımı yapmıştır. Fakat bu projede de hayvanlardan istenen verim alınamadığından başarısızlıkla sonuçlanmıştır. Buradan araştırma kapsamında ele alınan tarımsal örgütlerin kamu kurumu destekli proje uygulama durumlarının yüksek olmasına karşın, kamu dışı destekli proje uygulamalarının olmadığı belirlenmiştir. Tarımsal örgütler tarafından uygulanan projelerde üyelere/ortaklara dağıtılan hayvan ırklarının bölge iklimine uygun olmadığı ve bu sebeple de projelerden beklenen verimin alınamadığı söylenebilir. Yılmaz ve Gül (2010) tarafından Adana ilinde yapılan araştırmada da tarım kooperatifleri aracılığıyla uygulanan süt sığırcılığı projelerinden ekonomik anlamda istenilen başarının elde edilemediği tespit edilmiştir. Çiftçi (2015) tarafından Konya Damızlık Koyun Keçi YB'nin “Halk Elinde Küçükbaş Hayvan Islah Projesi” projesinin en önemli yürütücüsünün olduğu belirtilmektedir. Kılıç Topuz (2017) tarafından Samsun ilinde yapılan araştırmada birliklerin sadece \%14'ünün proje uyguladığı, \%50'sinin herhangi bir proje başvurusunun olmadığı tespit edilmiştir. Tarımsal örgütlerin kırsal kalkınmanın gerçekleşmesinde etkin rol alabilmesi için başarılı proje uygulaması ve hayata geçirmesi oldukça önemlidir. Araştırma bölgesindeki kooperatif ve birliklerinde dış kaynaklı projeleri hayata geçirmeleri, bölgenin ve örgütlerin kalkınması açısından kaçınılmazdır. Yılmaz ve Gül (2010) tarafından yapılan çalışmada da tarımsal kooperatiflerin yaygınlaştııılması, iyileştirilmesi ve kırsal kalkınmanın gerçekleşmesi için kooperatiflere yönelik projelerin artırılması gerektiği ve proje kapsamında dağıtılacak hayvanların bölge iklimine uygun olması gerektiği belirtilmektedir. 
Çizelge 6. Tarımsal örgütlerin başvurdukları/uyguladıkları projeler

Table 6. Applied and implement projects by agricultural organizations

\begin{tabular}{|c|c|c|c|c|c|}
\hline & & Ar1 YB & DKKYB & Gaziler TKK & $\begin{array}{l}\text { Bulakbaşı } \\
\text { TKK }\end{array}$ \\
\hline \multirow{5}{*}{ 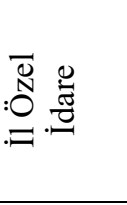 } & Uygulanma tarihi & 2018-19 & & & \\
\hline & Proje Ad 1 & Arı ile Gelen & & & \\
\hline & & Refah & & & \\
\hline & Toplam Bütçe (Bin TL) & 190 & & & \\
\hline & Başarı Durumu & Başarılı & & & \\
\hline \multirow{5}{*}{ 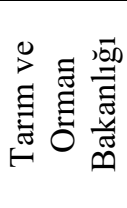 } & Uygulanma tarihi & 2018 & 2018 & 2009 & \\
\hline & Proje Ad 1 & Genç Çiftçi & 300 Koyun & Damızlık Sığır & \\
\hline & & Projesi & Projesi & Projesi (6x50) & \\
\hline & Toplam Bütçe (Bin TL) & 330 & - & 3,000 & \\
\hline & Başarı Durumu & Başarılı & Başarılı & Başarılı & \\
\hline \multirow{5}{*}{ 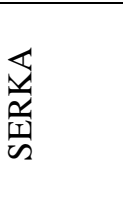 } & Uygulanma tarihi & & 2013 & & \\
\hline & Proje Adı & & Saanen Keçisi & & \\
\hline & & & Projesi & & \\
\hline & Toplam Bütçe (Bin TL) & & 90 & & \\
\hline & Başarı Durumu & & Başarılı & & \\
\hline
\end{tabular}

\subsection{Tarımsal örgütlerin sorunları ve diğer tarım paydaşları ile ilişkiler}

Iğdır ilindeki incelenen tarımsal örgütlerin en önemli sorunlarının finansman yetersizliği, üyelik aidatlarının düzenli olarak ödenmemesi, devlet desteğinin yetersiz olması ve tarımsal desteklerin örgütler aracılığıla verilmemesi olduğu belirlenmiştir. Sermaye yetersizliği yaşayan tarımsal örgütler, gerekli faaliyetleri etkili olarak gerçekleştirememektedirler. Birlik/kooperatiflerin diğer sorunları ise üyelerin eğitim seviyesinin düşük olması, ürünlerin pazarlanamaması, örgütler ve üyeler arasındaki güven eksikliği şeklindedir. Serinikli ve Kumkale (2012) tarafından Türkiye'deki üst örgütlerin sorunları incelenmiş ve en önemli sorunlarının sırasıyla; finansman yetersizliği, mevzuat yetersizliği ve ortakların ilgisizliği olduğu belirlenmiştir. Yücel ve Acar (2018) tarafindan Sinop ili Su Ürünleri Kooperatifleriyle yaptıkları araştırmada da temel sorunlar; ortak sayısı yetersizliği, yeni ortak katılımı olmaması, ortakların düzenli aidat ödememesi ve kooperatif konusunda ortakların risk almaması olarak belirlenmiştir. Kılıç Topuz ve Bozoğlu (2018) tarafından Samsun ilindeki Fındık Tarımsal Üretici Birliklerinin en önemli sorunları sırasıyla; kayıt dışı üretim, sermaye yetersizliği, devlet desteğinin yetersizliği ve aracıların rekabette üstün olması olarak belirlenmiştir. Tarımsal örgütlerin belirlenen hedeflerine ulaşmalarında bölgedeki diğer paydaşlar ile olan ekonomik ve sosyal ilişkilerinin geliştirilmesi oldukça önemlidir. Araştırmada birlik/kooperatiflerin bölgedeki diğer tarım paydaşlarından Iğdır Üniversitesi ve sosyal çevre (bölgedeki diğer üreticiler, tarım ile ilgili bilgi alışverişinde bulunulan kurum ve kuruluşlar, vs.) ile en güçlü ilişkiye sahip oldukları belirlenmiştir. Tarımsal örgütlerin bölgedeki Ziraat Odası ve Tarım Kredi Kooperatifleriyle ilişkilerinin genel olarak zayıf olduğu söylenebilir. Çiftçi (2015)'nin Konya ili Damızlık Koyun Keçi Yetiştirici Birliği konusunda yaptığı araştırmasında birliğin bölgedeki diğer birliklerle olan iş birliğinin iyi düzeyde olduğunu, teknik destek, danışmanlık, mevzuat, toplantı ve eğitimlere iştirak konusunda birbirleri ile sürekli yardımlaşma içerisinde olduğunu belirtmektedir. Kılıç Topuz (2017) tarafından Samsun ili Tarımsal Üretici Birliklerinde yapılan araştırmada ise birliklerin sosyal çevreleriyle ve Tarım İl Müdürlüğü ile en güçlü, üniversite, Tarım Kredi ve Tarım Satış Kooperatifleri ile en zayıf ilişkiye sahip olduğu tespit edilmiştir. Acar ve Yıldırım (2000), Van ilindeki tarımsal kalkınma kooperatiflerinin Yüzüncü Yıl Üniversitesi ile güçlü ilişki içerisinde olmalarının, bu kooperatiflerin tanınmasına ve bölgedeki itibarlarının artmasında önemli katkılarının olduğunu ortaya koymuştur. 
Çizelge 7. Birlik/kooperatiflerin sorunları ve bölgedeki paydaşlar ile ilişkileri

Table 7. Problems and relationship with stakeholders in the region of unions and cooperatives

\begin{tabular}{|c|c|c|c|c|c|c|}
\hline Sorunlar* & $\begin{array}{l}\text { Ar1 } \\
\text { YB }\end{array}$ & DKKYB & $\begin{array}{l}\text { Gaziler } \\
\text { TKK }\end{array}$ & $\begin{array}{l}\text { Bulakbaşı } \\
\text { TKK }\end{array}$ & $\begin{array}{l}\text { Toplam } \\
\text { skor }\end{array}$ & $\begin{array}{l}\text { Önem } \\
\text { siras1 }\end{array}$ \\
\hline Finansman yetersizliği & 5 & 5 & 5 & 5 & 20 & 1 \\
\hline $\begin{array}{l}\text { Üyelik aidatlarının düzenli olarak } \\
\text { ödenmemesi }\end{array}$ & 5 & 5 & 5 & 5 & 20 & 1 \\
\hline Devlet desteğinin yetersizliği & 5 & 5 & 5 & 5 & 20 & 1 \\
\hline $\begin{array}{l}\text { Tarımsal desteklerin birlik/kooperatif } \\
\text { aracılığıyla verilmemesi }\end{array}$ & 5 & 5 & 5 & 5 & 20 & 1 \\
\hline Üyelerin eğitim seviyesinin düşüklüğü & 4 & 5 & 5 & 5 & 19 & 2 \\
\hline Ürünlerin pazarlanamaması & 5 & 1 & 5 & 5 & 16 & 3 \\
\hline Örgüt-üye arasında güven eksikliği & 4 & 1 & 4 & 5 & 14 & 4 \\
\hline Kayıt dışı üretim & 5 & 1 & 5 & 1 & 12 & 5 \\
\hline Aracıların rekabette üstün olması & 5 & 1 & 5 & 1 & 12 & 5 \\
\hline Personelin niteliksiz oluşu & 3 & 1 & 3 & 5 & 12 & 5 \\
\hline Yetersiz tarım danışmanı & 3 & 1 & 3 & 5 & 12 & 5 \\
\hline Yöneticilerin kötü yönetimi & 2 & 1 & 3 & 5 & 11 & 6 \\
\hline Örgütün yeterince denetlenmemesi & 1 & 1 & 4 & 5 & 11 & 6 \\
\hline $\begin{array}{l}\text { Üreticilerin örgütlenme bilincinin düşük } \\
\text { olmas1 }\end{array}$ & - & - & 5 & - & 5 & 7 \\
\hline \multicolumn{7}{|l|}{ Paydaşlar** } \\
\hline Iğdır Üniversitesi & 5 & 5 & 4 & 1 & 15 & 1 \\
\hline Sosyal çevre & 4 & 5 & 4 & 1 & 14 & 2 \\
\hline Tarımsal Kalkınma Kooperatifleri & 1 & 5 & 4 & 3 & 13 & 3 \\
\hline Tarım ve Orman İl Müdürlüğü & 3 & 5 & 4 & 1 & 13 & 3 \\
\hline Merkez Birliği & 5 & 5 & 1 & 1 & 12 & 4 \\
\hline Ziraat Odası & 2 & 5 & 3 & 1 & 11 & 5 \\
\hline Tarım Kredi Kooperatifleri & 1 & 5 & 1 & 1 & 8 & 6 \\
\hline Toplam ilişki skoru & 21 & 35 & 21 & 9 & - & - \\
\hline
\end{tabular}

* 1. Önemsiz, ..., 5. Çok önemli, ** 1. Yok, ..., 5. Çok iyi

\subsection{Tarımsal örgüt yöneticilerinin profili}

Tarımsal örgüt yöneticilerinin ortalama yaşı 50 olup, ortalama eğitim seviyeleri lisedir. Birlik yöneticilerinin \%50'si üniversite mezunu, \%25'i ilkokul, \%25'i lise mezunudur. Bulakbaşı TKK yöneticisinin sosyal güvencesi yoktur (Çizelge 8). Everest ve ark. (2019) tarafindan Çanakkale ilinde yapılan araştırmada ortalama 49 yaşında olan tarımsal kalkınma kooperatifi yöneticilerinin \%58'inin ilkokul, \%17'sinin ortaokul, \%21'inin lise, \%2'sinin meslek yüksekokulu ve \%2'sinin ise üniversite mezunu olduğu belirlenmiştir. Başaran (2003)'ın Tekirdağ ilinde yaptığ1 diğer bir çalışmada kooperatif yöneticilerinin \%29.3'ünün ilkokul, \%21.9'unun ortaokul, \%26.8'inin lise ve \%22'sinin üniversite mezunu olduğu tespit edilmiştir. Şahin ve ark (2015)'nin araştırmalarında Türkiye'deki tarımsal kalkınma kooperatif yöneticilerinin ortalama 48 yaşında olduğu, \%35.7'sinin ilkokul, \%15.5'inin ortaokul, \%28.6'sının lise, \%3.6'sının yüksek okul ve \%16.7'sinin üniversite mezunu olduğu belirlenmiştir. Aydoğdu ve ark. (2015) tarafından Harran Ovasındaki Sulama Birlik başkanlarının ortalama 48 yaşında oldukları ve ortalama 7.22 yıl eğitime sahip oldukları belirlenmiştir. Buradan Iğdır ilindeki tarımsal örgüt yöneticilerinin eğitim durumlarının Türkiye'deki tarımsal kalkınma kooperatifi ortalamasından ve Sulama Birlik başkanlarından daha yüksek olduğu söylenebilir. 
Çizelge 8. Birlik/kooperatif yönetim kurulu başkanlarının demografik özellikleri

Table 8. Demographic characteristics of the executive board of unions and cooperatives

\begin{tabular}{|c|c|c|c|c|c|c|c|c|c|}
\hline \multirow[b]{2}{*}{ Örgüt adı } & \multirow[b]{2}{*}{ Yaş } & \multirow{2}{*}{$\begin{array}{l}\text { Eğitim } \\
\text { (y1l) }\end{array}$} & \multicolumn{3}{|c|}{ Eğitim Durumu (\%) } & \multicolumn{4}{|c|}{ Sosyal güvence (\%) } \\
\hline & & & İlkokul & Lise & Üniversite & Yok & SGK & Bağ-Kur & $\begin{array}{l}\text { Emekli } \\
\text { Sandığ } 1\end{array}$ \\
\hline Ar1 YB & 35 & 15 & & & + & & + & & \\
\hline DKKYB & 55 & 11 & & + & & & & & + \\
\hline Gaziler TKK & 51 & 15 & & & + & & & + & \\
\hline Bulakbaşı TKK & 60 & 5 & + & & & + & & & \\
\hline $\begin{array}{l}\text { Ortalama/ } \\
\text { Oran (\%) }\end{array}$ & 50 & 11.5 & 25.0 & 25.0 & 50.0 & 25.0 & 25.0 & 25.0 & 25.0 \\
\hline
\end{tabular}

Yönetim kurulu, ilgili yönetmelik ve anasözleşme hükümleri doğrultusunda kooperatif/birliğin faaliyetlerini yöneten ve kooperatif/birliği temsil eden icra organıdır. Denetim kurulu ise genel kurul namına kooperatif/birliğin bütün işlem ve hesaplarını inceleyen organdır. Yönetim kurulu ve denetim kurulu üyeleri en az üç üyeden oluşmaktadırlar (RG, 1969; RG, 2001). Araştırma kapsamında ele alınan tarımsal örgütlerin yönetimi ile ilgili bilgiler 5 yönetim kurulu üyesi ve 3 denetim kurulu üyesi olacak şekilde alınmıştır. Araştırma kapsamında ele alınan tarımsal örgütlerin yönetim kurulu üyelerinin ortalama eğitim seviyesi 9 yıl, denetim kurulu üyelerinin ise 8 yıldır. Tarımsal örgütlerde en eğitimli yönetim kurulu üyeleri (12.6 yıl) ve denetim kurulu üyeleri (11 yıl) Arı YB'nde yer alırken, en eğitimsiz yönetim kurulu ve denetim kurulu üyeleri (5 yıl) ise Bulakbaşı TKK’nde yer aldığ görülmektedir. Birlik veya kooperatif yöneticileri yılda ortalama 1 kongre, seminer ve fuar gibi etkinliklere katılmaktadırlar ve en fazla kongre, seminer, fuar gibi etkinliklere katılan yöneticiler Damızlık Koyun Keçi YB yöneticileridir. Araştırmada tarımsal örgütlerin \%75'inin bir kez örgütlenme konusunda eğitim aldığı belirlenmiştir. Tarımsal örgütlerin denetim kurulu üyelerinin ise katıldığg kongre, seminer, fuar gibi etkinlik ve örgütlenme eğitimi yok denecek kadar azdır (Çizelge 9). Şahin ve ark (2015)'nın çalışmasında Türkiye'deki tarımsal kalkınma kooperatifleri yöneticilerinin \%46.4'ünün kooperatifçilik eğitimi aldığı, \%53.6'sının ise eğitim almadığı belirlenmiştir. Everest ve ark. (2019)'ın çalışmasında Çanakkale ilindeki tarımsal örgüt yöneticilerinin \%69'unun son bir yılda tarımla ilgili bir toplantıya katıldıkları belirlenmiştir. Tarımsal örgütlerin etkili olarak faaliyetlerini devam ettirebilmesi için yöneticilerin, üyelerin ve çalı̧̧anların kooperatifçilik ve/veya örgütlenme konusunda eğitilmeleri kaçınılmazdır. Bu konuda alanında uzman kişilerden ve üniversitelerden sürekli olarak yararlanılması gerekmektedir.

Çizelge 9. Birlik/kooperatif yöneticilerinin eğitim durumu, kongreye katılma ve örgütlenme eğitimi alma durumları Table 9. Status of education, participation to congress and organization training of the unions/cooperatives managers

\begin{tabular}{|c|c|c|c|c|c|c|c|c|c|c|}
\hline \multirow[b]{3}{*}{ Örgüt adı } & \multicolumn{5}{|c|}{ Yönetim Kurulu Üyeleri } & \multicolumn{5}{|c|}{ Denetim Kurulu Üyeleri } \\
\hline & \multicolumn{3}{|c|}{ Eğitim durumu (y1l) } & \multirow{2}{*}{$\begin{array}{l}\text { Katıldığ1 } \\
\text { kongre/ } \\
\text { seminer/ } \\
\text { fuar (kez) }\end{array}$} & \multirow{2}{*}{$\begin{array}{l}\text { Örgütlenme } \\
\text { Eğitimi } \\
\text { alma (kez) }\end{array}$} & \multicolumn{3}{|c|}{ Eğitim durumu (yıl) } & \multirow{2}{*}{$\begin{array}{c}\text { Katıldığ } 1 \\
\text { kongre/ } \\
\text { seminer/fuar } \\
(\mathrm{kez})\end{array}$} & \multirow{2}{*}{$\begin{array}{l}\text { Örgütlenme } \\
\text { Eğitimi } \\
\text { alma (kez) }\end{array}$} \\
\hline & Ort. & Min. & Max. & & & Ort. & Min. & Max. & & \\
\hline Ar1 YB & 12.6 & 11 & 15 & 1 & 1 & 11 & 11 & 11 & - & - \\
\hline DKKYB & 8.6 & 5 & 11 & 3 & 1 & 7.3 & 5 & 11 & 1 & - \\
\hline $\begin{array}{l}\text { Gaziler } \\
\text { TKK }\end{array}$ & 10 & 5 & 15 & 1 & 1 & 9 & 8 & 11 & 1 & 1 \\
\hline $\begin{array}{l}\text { Bulakbaşı } \\
\text { TKK }\end{array}$ & 5 & 5 & 5 & - & - & 5 & 5 & 5 & - & - \\
\hline Ortalama & 9.05 & 6.5 & 11.5 & 1.25 & 0.75 & 8.07 & 7.25 & 9.5 & 0.5 & 0.25 \\
\hline
\end{tabular}




\section{Sonuç ve Öneriler}

Iğdır İlinde hane halklarının önemli bir kısmının temel geçim kaynağını tarımsal faaliyetler oluşturmaktadır. Iğdır İlinde çok az sayıda tarımsal örgüt mevcut olup, mevcut tarımsal örgütlerin tamamı hayvancılık alanında faaliyet göstermektedir. Üreticilerin sorunlarına çözüm bulabilmesi ve piyasada daha etkili olabilmeleri için bitkisel üretim konusunda da tarımsal örgüt kurulması teşvik edilmeli ve kurulmalıdır. Aktif üye oranı çok düşük olan tarımsal örgütlerin sermayeleri ve üyelerine sunduğu hizmetler çok yetersizdir. Tarımsal kooperatif ve birliklerin büyük çoğunluğunda giriş sermayesi ve üyelik aidatı alınmasına rağmen, aidatını düzenli ödeyen üyelerin oranı düşüktür. Tarımsal kooperatif ve birliklerin kamu kurumları destekli proje uygulama oranları yüksek olmasına rağmen, kamu dışı destekli proje uygulama oranları yeterli düzeyde değildir. Tarımsal örgütlerin sermayelerinin artırılabilmesi ve üyelerine daha fazla hizmet sunabilmesi için proje yürütmeleri çok önemlidir. Bu sebeple, tarımsal örgüt yöneticileri bu konuda bilinçlendirilmeli ve ilgili kurum ve kuruluşlar tarafindan proje hazırlama ve uygulama konusunda eğitim verilerek kapasitelerinin güçlendirilmesi önem arz etmektedir. Ayrıca, tarımsal örgütlerin bölgedeki diğer tarım paydaşları ile ilişkileri zayıf ve genel kurul toplantılarına üye katılım oranları oldukça düşüktür. Oysa, çiftçi örgütlerinin sorunlarının çözülebilmesi, ekonomik ve sosyal yönden gelişebilmesi için bölgede yer alan tüm paydaşların iş birliği içerisinde olması gerekmektedir. Üyelerin tarımsal örgüt ve yöneticilerine güvenlerinin artması için genel kurul toplantılarına katılımları çok önemli olduğundan üyelerin genel kurul toplantılarına katılımlarını artırıcı önlemler uygulamaya geçilmelidir. Araştırma kapsamında ele alınan tarımsal örgüt yöneticilerinin eğitim seviyesinin yüksek olmasına karşın, tarımsal örgütlenme konusunda yeterli eğitim almadıkları belirlenmiştir. Yöneticilerin örgütlenme konusunda bilgi düzeylerinin artırılması için eğitim almaları kaçınılmaz olup, bu konuda bölgedeki üniversiteden ve uzman kişilerden yararlanılmalıdır. Araştırmada ele alınmayan ve Iğdır İlinde faaliyet gösteren tarım kredi kooperatiflerinde de benzer bir araştırmaların yapılması, bölgenin kalkınmasına yarar sağlayabilecektir.

\section{Teşekkür}

Bu çalışma Iğdır Üniversitesi 2019-FEB-A10 No’lu Bilimsel Araştırma Projesi ile desteklenmiştir.

\section{Kaynaklar}

Acar, İ., Yıldırım, İ., 2000. Mandıra işleten Dönerdere Tarımsal Kalkınma Kooperatifine ortak işletmelerin ekonomik analizi. Yüzüncü Yıl Üniversitesi Ziraat Fakültesi Tarım Bilimleri Dergisi, 10(1): 61-70.

Alptekin, B., 2018. Tarımsal üretim ve pazarlama açısından örgütlenme (organizasyon) sorununun, hayvancıllk işletmelerinde analizi: Iğdır örneği. Yüksek Lisans Tezi. Iğdır Üniversitesi Fen Bilimleri Enstitüsü, 86s, Iğdır.

Anonim, 2020. Tarım ve Orman Bakanlığı Iğdır İl Tarım ve Orman Müdürlüğü, https://igdir.tarimorman.gov.tr/Menu/20/Ilimiz (Erişim tarihi: 18 Aralık 2020).

Aydoğdu, M.H., Karlı, B., Yenigün, K., Manc1, A.R., Aydoğdu, M., 2014. Harran Ovasındaki sulama birliklerinin yapısal sorunları ve çözüm önerileri, GAP Bölgesi. Türkiye. The Journal of Academic Social Science Studies, 28, 179-196.

Aydoğdu, M.H., Mancı, A.R., Aydoğdu, M., 2015. Sulama Birlik başkanlarının su yönetimine bakışları ve yeterlilikleri: GAP-Harran Ovası sulamaları örneklemesi. Harran Tarım ve Gıda Bilimleri Dergisi, 19(3): 172-179.

Başaran, B., 2003. Uluslararası Çalışma Örgütü’nün yeni kooperatif standartları ve ülkemiz kooperatiflerinin uyumu: Trakya Bölgesi tarım kooperatifleri örneği. Yüksek Lisans Tezi. Trakya Üniversitesi, Fen Bilimleri Enstitüsü, 161s, Trakya.

Bozoğlu, M., Cinemre, H.A., Ceyhan, V., 2001. Tarımsal sanayinin geliştirilmesinde kooperatifleşme: Tonya örneği. Ondokuz Mayıs Üniversitesi Ziraat Fakültesi Dergisi, 16(2): 23-29.

Çiftçi, İ., 2015. Damızlık Koyun-Keçi Yetiştiricileri Birliklerinin sürdürülebilir işletmecilik modeli: Konya ili örneği. Yüksek Lisans Tezi. Selçuk Üniversitesi Fen Bilimleri Enstitüsü, 86s, Konya.

Everest, B., Yercan, M., Tan, S., 2019. Tarımsal kalkınma, sulama ve su ürünleri kooperatiflerinde kurumsal yap1 ve yönetici profilinin tespiti: Çanakkale İli örneği. Türk Tarım ve Doğa Bilimleri Dergisi, 6(2): 343-353.

ICA, 2021. International Co-operative Alliance, Available from https://www.ica.coop/en/our-work/worldcooperative-monitor (Erişim tarihi: 3 Ocak 2021). 
Karadaş, K., Şahin, K., Ertürk, E., Demir, O., 2014. Iğdır İli tarım işletmelerinde örgütlenme bilincinin belirlenmesi. XI. Ulusal Tarım Ekonomisi Kongresi, 1221-1226, 3-5 Eylül 2014, Samsun.

Karadaş, K., Ertürk, Y.E., Demir, O., Külekci, M., Demir, N., 2015. Iğdır İlinde kırsal kalkınma kooperatifi üyelerinin örgütlenme ve kooperatif faaliyetleriyle ilgili problemleri ve çözüm önerilerinin belirlenmesi. Üçüncü Sektör Sosyal Ekonomi Dergisi, 50(2): 152-162.

Kılıç Topuz, B., 2017. Samsun İli tarımsal üretici birliklerinde güven ve performansa etkili faktörler. Doktora Tezi. Ondokuz Mayıs Üniversitesi Fen Bilimleri Enstitüsü, 430s, Samsun.

Kılıç Topuz, B., Bozoğlu M. 2015. Samsun İlindeki tarımsal kalkınma kooperatiflerinde ortak-kooperatif ilişkilerinin analizi. Anadolu Tarım Bilimleri Dergisi, 30 (3): 246-253.

Kılıç Topuz, B., Bozoğlu, M., 2016. Tarımsal üretici birliklerinde performans ölçümü. Anadolu Tarım Bilimleri Dergisi, 31(2016): 360-369.

Kılıç Topuz, B., Bozoğlu, M., 2018. Samsun İlindeki fındık tarımsal üretici birliklerinin mevcut durum analizi. Iğdır Üniversitesi Fen Bilimleri Enstitüsü Dergisi, 8(4): 325-335.

Özüdoğru, H., 2004. Köy-Koop Kırklareli Birliği’nin ekonomik analizi ve yöneticilerin kooperatif işletmelerinin başarısına etkilerinin değerlendirilmesi. Doktora Tezi. Ankara Üniversitesi Fen Bilimleri Enstitüsü, 172s, Ankara.

Rehber, E., 1993. Tarımda örgütlenme ve kooperatif̧̧ilik. Kooperatifçilik Dünyası Dergisi. Sayı: 271.

RG, 1969. 1163 sayılı Kooperatifler Kanunu, 24.04.1969 tarih 13195 Sayılı Resmi Gazete.

RG, 2001. 4631 Sayılı 1slah amaçlı yetiştirici birliklerinin kurulması ve hizmetleri hakkında yönetmelik, 10.03.2001 tarih 24338 sayılı Resmi Gazete.

Serinikli, N., Kumkale, İ., 2012. Türkiye'deki kooperatif üst örgütlerinin (Bölge Birliklerinin) sorunları ve çözüm önerileri. Trakya Üniversitesi Sosyal Bilimler Dergisi, 14(1): 269-290.

Şahin, A., Miran, B., Cankurt, M., Günden, C., Kaynakçı, C., 2015. Türkiye'de tarımsal kalkınma kooperatiflerinde yöneticilerin özellikleri. Kahramanmaraş Sütçü İmam Üniversitesi Tarım ve Doğa Dergisi., 18(1): 1-12.

Talim, M., Güneş, T., Çıkın, A., İnan, İ.H., Bektöre, M., 1981. Tarımda teşkilatlanma. Türkiye II. Tarım Kongresi, Tebliğler Kitabı, Tarım ve Orman Bakanlığı Yayınları, Ankara.

TRGM, 2021. Tarım ve Orman Bakanlığı, Tarım Reformu Genel Müdürlüğü, https://www.tarimorman.gov.tr/TRGM/Link/33/Tarimsal-Orgutlenme-Tablosu (Erişim tarihi: 3 Ocak 2021).

TÜİK, 2020. Türkiye İstatistik Kurumu, https://data.tuik.gov.tr/Bulten/Index?p=Nufus-Projeksiyonlari-2018-208030567 (Erişim tarihi: 18 Aralık 2020).

Ünal, V., Göncüoğlu, H., Sarı, H.M., 2011. Ege Bölgesi İçsu kooperatiflerinin mevcut durumu, problemleri ve ileriye yönelik projeleri. Su Ürünleri Dergisi, 28(2): 47-52.

Yılmaz, H., Gül, A. 2010. Adana İlinde kooperatifler aracılığıyla uygulanan süt sığırcılığı projelerinin genel bir değerlendirmesi. Türkiye IX. Tarım Ekonomisi Kongresi, 534-541, 22-24 Eylül, Şanlıurfa.

Yücel, Ş., Acar, G., 2018. Su ürünleri kooperatifleri yöneticilerinin sosyo-ekonomik durumu ve kooperatiflerin sorunlarına bakışı. Gaziosmanpaşa Bilimsel Araştırma Dergisi, 7(2): 57-66. 